DOI: https://doi.org/10.32839/2304-5809/2021-4-92-69

уДК 336.4

Ситник Н.C., Дунець I.A.

Львівський національний університет імені Івана Франка

\title{
ЛІЗИНГ ЯК ФОРМА ОНОВЛЕННЯ ТЕХНІЧНОЇ БАЗИ ПІДПРИСМСТВА
}

\begin{abstract}
Анотація. У статті досліджено сутність лізингу, його види та законодавче обгрунтування. Охарактеризовано елементну структуру лізингових операцій. Наведено переваги використання лізингу як форми оновлення технічної бази на підприемстві. Зазначено сутність, передумови поширення та розвиток фінансового лізингу. Проведено аналіз динаміки фінансового лізингу в Україні впродовж 2017-2019 років. Досліджено сприятливі сфери економіки для еффективного використання фінансового лізингу та основні показники діяльності лізингодавців в Україні. Представлено досвід зарубіжних країн у підтримці розвитку лізингу у період його становлення та рівні забезпечення його регулювання. Визначено законодавчі проблеми поширення лізингу та можливості для лізингоотримувача від використання лізингу як форми оновлення технічної бази підприемства.
\end{abstract}

Ключові слова: лізинг, фінансовий лізинг, лізингові операції, оренда, договір.

Sytnyk Nataliia, Dunets Iryna Lviv Ivan Franko National University

\section{LEASING AS A FORM OF UPDATING THE TECHNICAL BASE OF THE ENTERPRISE}

Summary. Leasing contributes to the rapid and high-quality renewal of the technical base of the enterprise, which is an important condition for its effective operation and development. The article examined the concept of leasing and its legal justification. In particular, an analysis of the dynamics of the spread of financial leasing in Ukraine during 2017-2019, described the elemental structure of leasing operations, presented the advantages of leasing in the enterprise, explored favorable areas of the economy for effective use of financial leasing. The article indicated the levels of leasing regulation in foreign countries, identified the main legislative problems of leasing and opportunities to use leasing as a form of updating enterprises. On the one hand, leasing has its drawbacks in the complexity of leasing agreements and the risks of non-payment of lease payments or non-return of the leased object, on the other hand leasing allows the company to sell capital more efficiently, increase productivity and provide the enterprise new and necessary basic means. Rapid changes and development of the world economy, requirements and standards caused by scientific and technological progress to the constant renewal of fixed assets, as well as the need for rational use of enterprise resources require an efficient and modern material and technical base. One of the effective ways to update it is leasing. The relevance of the spread of leasing in enterprises lies in the significant number of its advantages and opportunities. Many scientists in their works have studied the spread of leasing operations, highlighted the issues and benefits of leasing, but the leasing market in Ukraine is not sufficiently developed. The possibilities of using leasing at the enterprise to update the technical base and the experience of foreign countries in regulating leasing operations require more detailed and in-depth study. The task of the article is to study leasing as a form of updating the technical base of the enterprise, to analyze the state of development of leasing activities in Ukraine, to identify shortcomings and opportunities from the use of leasing in the enterprise.

Keywords: leasing, financial leasing, leasing operations, rent, agreement.

Постановка проблеми. Швидкі зміни 1 та розвиток світової економіки, вимоги та стандарти визначені науково-технічним прогресом до постійного оновлення основних засобів, а також необхідність раціонального використання ресурсів підприемства потребують ефективної та сучасної матеріально-технічної бази. Одним з ефективних способів її оновлення є лізинг.

Аналіз останніх досліджень і публікацій. Дослідженню рівня розвитку та поширення лізингу присвячені роботи таких науковців, як: Н. Ярошевич, Н. Брюховецька, В. Андрійчук, В. Газман, В. Черненко, О. Баєва, О. Петрук та інших. Проблемами підвищення ефективності використання лізингу і порівняння його переваг з недоліками відображені у наукових працях вчених: О. Гриценка, М. Лещенка, В. Міщенка, В. Терещенка, Я. Усенка та інших.

Виділення невирішених раніше частин загальної проблеми. В сучасних умовах лізинговий ринок України не $є$ достатньо розвинутий. Тому необхідно розглянути питання доцільності використання лізингу на підприемствах Украї- ни, детальніше вивчити досвід зарубіжних країн в регулюванні лізингових операцій та можливості від застосування лізингу як форми оновлення технічної бази.

Завдання статті полягає у дослідженні сутності лізингу як форми оновлення технічної бази підприемства, аналізу стану розвитку лізингової діяльності та визначенню недоліків і можливостей від її використання на підприемствах України.

Виклад основного матеріалу. Лізинг розглядають як довгострокову оренду майна, що діє на умовах платності, строковості та зворотності або викупу. 3 одніеї сторони лізинг можна трактувати як своєрідну форму фінансування або інвестицій, а з іншої - як форму реалізації та каналу збуту продукції.

Відповідно до Закону України «Про лізинг», лізинг - це підприємницька діяльність, яка спрямована на інвестування власних чи залучених фpiнансових коштів і полягає в наданні лізингодавцем у виключне користування на визначений строк лізингоодержувачу майна, що є власністю лізингодавця або набувається ним у власність за дорученням 
і погодженням з лізингоодержувачем у відповідного продавця майна, за умови сплати лізингоодержувачем періодичних лізингових платежів [1].

Об'єктом лізингу може бути як рухоме, так і нерухоме майно, що відносять до основних засобів. До них належать машини, устаткування, техніка, транспорт тощо, але за умови, що на дане майно немає заборони передавання у лізинг. Договори лізингу не поширюються на об'єкти оренди державного майна. Суб'єктами лізингової операції, як правило, є виробник, лізингодавець, лізингоодержувач, банк та страхова установа. Особливістю лізингової діяльності $є$ те, що зазвичай замовник викуповуе в лізингодавця обладнання після використання за залишковою вартістю.

Залежно від терміну використання об'єкта лізингу його поділяють на оперативний, тобто iз неповною окупністю i фінансовий (з повною окупністю). Під час оперативного лізингу технічне обслуговування та ремонт засобів праці виконуе лізингодавець. За масштабом поширення лізинг може бути внутрішній, та міжнародний. За характером лізингові операції поділяються на сервісні та зворотні. Сервісний лізинг, як правило, поширюеться за основні засоби, що зазнають швидкого морального зносу, наприклад транспорт або комп'ютерно-обчислювальна техніка.

Законодавче обтрунтування лізингових операцій реалізується відповідно до Закону України «Про лізинг». Між суб’єктами лізингу укладається договір, який у письмовій фрормі встановлює та систематизуе взаємовідносини та домовленості між ними. Термін його дії визначається за рішенням учасників.

Зокрема, відповідно до вищезазначеного закону лізингодавець зобов'язаний передати об’єкт лізингу лізингоодержувачу відповідно до умов, зазначених в договорі; повідомити лізингоодержувача про стан та особливості об'єкта лізингу; утримувати предмет лізингу згідно з умовами, зазначеними в угоді про лізинг; своєчасно і в повному обсязі виконувати взяті на себе зобов'язання щодо утримання об'єкта лізингу відповідно до умов договору.

Лізингоодержувач зобов'язаний утримувати предмет лізингу та користуватися ним відповідно до його призначення; вчасно виплачувати лізингові платежі; повідомляти лізингодавця про стан об'єкта лізингу; повернути предмет лізингу в стані, в якому його було прийнято у володіння.

Для підприємства лізинг надає можливість використовувати капітал, що залишаеться від оренди, а не купівлі, основних засобів, для інших видів діяльності та одержання додаткового доходу. Завдяки довгостроковій оренді підприемства можуть забезпечити власне виробництво новою, якісною та ефективною технікою. Такий спосіб оновлення технічної бази має безліч переваг, зокрема підвищуе продуктивність праці.

Однією 3 основних причин стрімкого поширення лізингу на підприємствах є швидке моральне та фрізичне старіння техніки (табл. 1).

За даними Державної служби статистки, у 2019 році ступінь зносу основних засобів у промисловості та транспорті становив 59,1 і 54,1 відсотків відповідно, що є найвищими показниками серед видів економічної діяльності. Загальний ступінь зносу основних засобі в Україні - 56,9\%.

У випадку нестачі коштів або неможливості отримання кредиту власне лізинг як форма довгострокової оренди надає можливість забезпечити виробництво потрібними основними засобами і тим самим оновлює технічну базу підприємства.

На наш погляд, ще однією перевагою поширення лізингу $е$ його доцільність використання саме для невеликих підприємств. Адже, забезпечити виробництво обладнанням у довгострокову оренду вигідніше, ніж платити його повну вартість. Лізинг сприятливий і для спещіалізованих проектів, що потребують великих вкладень капіталу, наприклад постачання транспортними компаніями літаків або суден.

В Україні лізинг поширюеться в результаті приватизації державних підприемств та створення малих та середніх субектів господарювання. Причинами необхідності використання лізингу стали невідповідність технічного стану більшості устаткування та низька ефективність його використання. Варто відзначити, що найбільш стрімко в Україні розвивається фрінансовий лізинг.

Фінансовий лізинг як вид цивільно-правових відносин передбачає договір, за якого лізингоодержувач одержуе в користування від лізингодавця об'єкт лізингу на термін, не менший за період його повної амортизащії. За умовами фінансового лізингу ризик втрати майна, а також здійснення його технічного обслуговування та ремонту бере на себе лізингоодержувач.

Лізинг вважається фінансовим, якщо договір містить одну з таких умов:

- об'єкт лізингу передається на строк, протягом якого амортизуеться не менш як $75 \%$ його первісної вартості, а орендар зобов'язаний на підставі лізингового договору та протягом стро-

Ступінь зносу основних засобів за видами економічної діяльності

Таблиця 1

\begin{tabular}{|l|c|c|c|}
\hline \multicolumn{1}{|c|}{$\begin{array}{l}\text { Основні засоби за видами економічної } \\
\text { діяльності }\end{array}$} & \multicolumn{3}{|c|}{ Ступінь зносу основних засобів, \% } \\
\cline { 2 - 4 } & $\mathbf{2 0 1 7}$ рік & $\mathbf{2 0 1 8}$ рік & $\mathbf{2 0 1 9}$ рік \\
\hline Усього & 55,1 & 60,6 & 56,9 \\
\hline Промисловість & 59,1 & 66,4 & 59,1 \\
\hline Будівництво & 45,7 & 44,5 & 51,4 \\
\hline $\begin{array}{l}\text { Оптова та роздрібна торгівля; ремонт } \\
\text { автотранспортних засобів і мотоциклів }\end{array}$ & 40,4 & 42,1 & 40,4 \\
\hline $\begin{array}{l}\text { Транспорт, складське господарство, поштова } \\
\text { та кур'ерська діяльність }\end{array}$ & 47,6 & 62,9 & 54,1 \\
\hline Сільське, лісове та рибне господарство & 35,7 & 35,4 & 38,3 \\
\hline
\end{tabular}

Джерело: розроблено автором за даними [3, с. 235] 
Основні показники діяльності лізингодавців

\begin{tabular}{|c|c|c|c|}
\hline Показник & $\begin{array}{c}\text { Станом на } \\
31.12 .2017 \\
\end{array}$ & $\begin{array}{c}\text { Станом на } \\
31.12 .2018 \\
\end{array}$ & $\begin{array}{c}\text { Станом на } \\
31.12 .2019 \\
\end{array}$ \\
\hline Кількість зареєстрованих установ & 183 & 167 & 157 \\
\hline $\begin{array}{l}\text { Кількість установ, які мають діючу ліцензію на право } \\
\text { надання послуг з фінансового лізингу, (од) }\end{array}$ & 94 & 116 & 113 \\
\hline Вартість діючих договорів фрінансового лізингу, (млн. грн.) & 22417,9 & 24920,9 & 27645,6 \\
\hline Кількість діючих договорів фінансового лізингу, (од.) & 13939 & 14472 & 16830 \\
\hline $\begin{array}{l}\text { Вартість договорів фінансового лізингу, } \\
\text { укладених за звітний період, (млн. грн.) } \\
\end{array}$ & 12814,2 & 21519,3 & 24647,8 \\
\hline $\begin{array}{l}\text { Кількість договорів фінансового лізингу, } \\
\text { укладених за звітний період, (од.) }\end{array}$ & 7699 & 8739 & 12363 \\
\hline
\end{tabular}

Джерело: розроблено автором за даними [5, с. 1]

ку його дії придбати об'єкт лізингу з наступним переходом права власності від орендодавця до орендаря за ціною, визначеною у такому лізинговому договорі;

- балансова (залишкова) вартість об'єкта лізингу на момент закінчення дії лізингового договору, передбаченого таким договором, становить не більш як 25\% первісної вартості ціни такого об'єкта лізингу, що діє на початок строку дії лізингового договору;

- сума лізингових платежів з початку строку оренди дорівнюе первісній вартості об'єкта лізингу або перевищуе їі;

- майно, що передається у фрінансовий лізинг, виготовлене за замовленням лізингоотримувача та після закінчення дії лізингового договору не може бути використаним іншими особами, крім лізингоотримувача, виходячи з його технологічних та якісних характеристик [4].

Важливою передумовою поширення фрінансового лізингу в Україні є не лише бажання підприємств модернізувати власне виробництво за допомогою довгострокової оренди, а й наявність достатньої кількості установ, які мають чинну ліценцію на право надання послуг 3 даного виду лізингу. За даними Державного реєстру, станом на кінець 2019 в Україні налічуеться 113 діючих установ лізингодавців (табл. 2).
Абсолютний темп приросту вартості договорів укладених протягом 2017-2019 років становить 11833, 6 мільйона гривень, а кількості - 4664 одиниць, що свідчить про тенденцію зростання.

Фінансовий лізинг ефективно використовується в різних галузях економіки України (рис. 1).

За даними рисунку 1, протягом 2019 року найбільше договорів фрінансового лізингу укладено з лізингоотримувачами у галузях:

- сільське господарство, вартість договорів становить 6 758,8 млн. грн.;

- транспорт, вартість договорів становить 5 262,4 млн. грн.;

- сорера послуг, вартість договорів становить 1 723,5 млн. грн.;

- харчова промисловість, вартість договорів 1557,1 млн. грн.

Результатом використання фрінансового лізингу як форми оновлення технічної бази є позитивний вплив на конкурентоспроможність підприемства, зміну обсягу і структури виробництва та покращення його технічного рівня. Зокрема, лізинг активно використовують в аграрній галузі України, оскільки рівень технічного оснащення та можливість застосовувати новітні технології $е$ важливими чинниками росту продуктивності пращі у сільскому господарстві

Варто зазначити, що фінансовий лізинг надає можливості для оновлення технічної бази підпри-

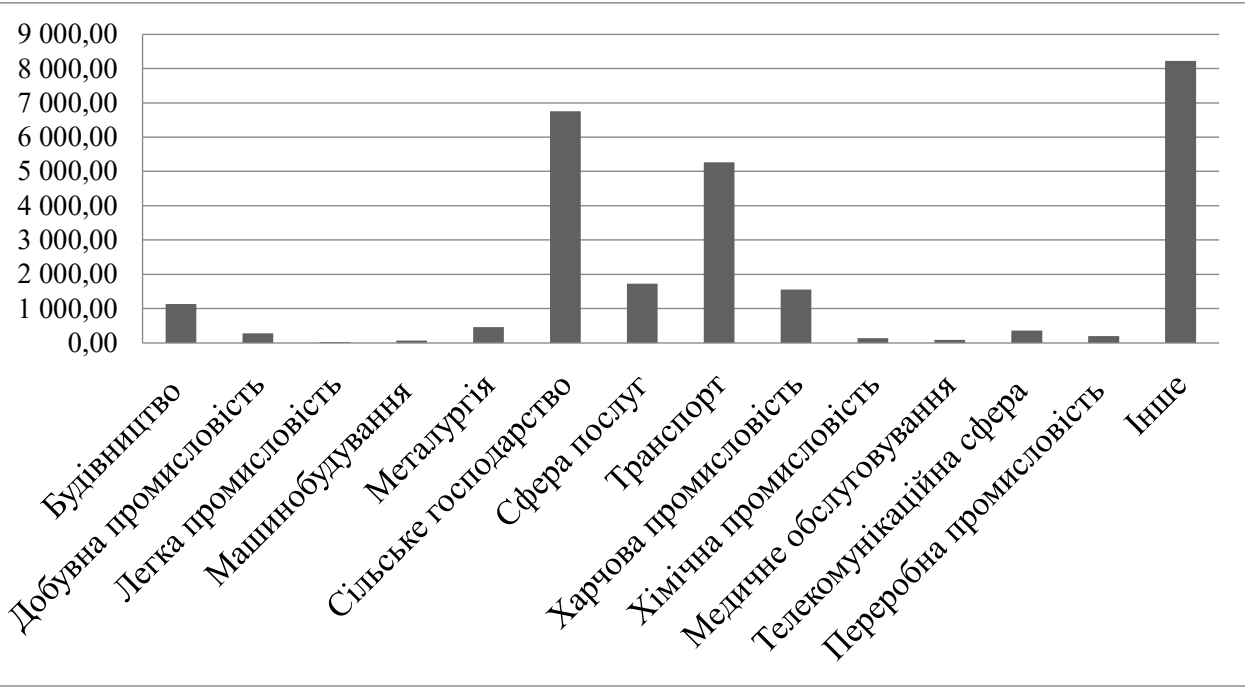

Рис. 1. Вартість договорів фінансового лізингу, укладених протягом 2019 року за галузями, млн. грн. 
Вартість договорів фінансового лізингу,

Таблиця 3

укладених за звітний період за обладнанням, млн. грн.

\begin{tabular}{|c|c|c|c|}
\hline Обладнання & 2017 рік & 2018 рік & 2019 рік \\
\hline Транспорт & 6735,7 & 15523,8 & 16450,2 \\
\hline Комп’ютерна техніка та телекомунікаційне обладнання & 4,9 & 44,1 & 21,5 \\
\hline Друкарське та поліграфрічне обладнання & 20,4 & 9,5 & 4,9 \\
\hline Торговельне обладнання & 6,7 & 2,6 & 2,2 \\
\hline Техніка, машини та устаткування для сільського господарства & 3043,7 & 5123,1 & 6701,0 \\
\hline Будівельне обладнання та техніка & 1190,0 & 822,9 & 1068,9 \\
\hline Обладнання для харчової переробки & 33,6 & 0,6 & 14,3 \\
\hline Медичне обладнання & 21,0 & 218,6 & 66,1 \\
\hline Промислове обладнання & 28,8 & 34,6 & 248,1 \\
\hline Будівлі та споруди & 560,9 & 10,5 & 1109,6 \\
\hline Інше & 1322,0 & 402,8 & 558,0 \\
\hline Всього & 12967,7 & 22193,1 & 26244,8 \\
\hline
\end{tabular}

Джерело: [5, с. 13]

ємств України за допомогою довгострокової оренди великої кількості різного обладнання (табл. 3).

3 таблиці 3 видно, що протягом 2019 року найчастіше фрінансувалися такі об'екти лізингу, як:

- транспорт - 16450,2 млн. грн., що становить $62,7 \%$ від суми всіх договорів. Порівняно з 2018 роком показник збільшився на $6,0 \%$.

- техніка, машини та устаткування для сільського господарства - 6701 млн. грн., або 25,5\% від загальної суми договорів.

- будівлі та споруди - 1 109,6 млн. грн., що становить 4,2\% від загальної суми договорів.

За даними Державного реєстру фінансових установ [5], в Україні найбільше договорів фрінансового лізингу укладено на термін від 2 до 5 років. У 2019 рощі вартість даних договорів становила 17 375,7 млн. грн. (табл. 4).

Попри щорічне збільшення вартості та кількості договорів фрінансового лізингу, в Україні лізинг лише розвивається на відміну від зарубіжних держав, де він набув поширення уже після Другої світової війни. У розвинених країнах фрінансовий лізинг існуе як певний вид інвестування виробництва, де основну увагу зосереджують на фінансовому аспекті договорів. Однак у переважній більшості міжнародних лізингових угод українські підприемства є лізингоотримувачами.

Варто зазначити, що існують різні рівні забезпечення регулювання лізингу в зарубіжних країнах:

- країни, які мають спеціальні закони, що регулюють лізингові угоди (Франція, Італія);

- країни, які мають особливе спеціальне лізингове законодавство (Швеція, Австрія);
- країни, які не мають спеціальних законів і підзаконних актів, які регулювали б лізингові угоди (Німеччина, Данія, США) [6].

У країнах з розвиненою економікою уряд надавав пільгове оподаткування для лізингових операцій, особливо у період їх становлення. Поширенню лізингу сприяло запровадження політики прискореної амортизації та інвестиційні знижки, які дають можливість зменшити величину прибутку до оподаткування. Найбільш вигідні умови для розвитку лізингового ринку створені у Великобританії, Ірландії, Норвегії. Половина світового обігу товарів, які постачаються за допомогою лізингу, припадає на США.

Німеччина, Британія та Польща є лідерами розвитку лізингового ринку у Свропі. Як правило, лізингові операції у цих країнах поширені більше ніж банківське кредитування. Зокрема, лізинговими послугами активно користуються підприемства малого бізнесу.

На нашу думку, варто враховувати досвід зарубіжних країн у становленні лізингу аби пришвидшити розвиток лізингових операщій в Україні. Стійка позитивна динаміка ринку лізингу протягом останніх років спричинена низкою сприятливих фракторів, серед яких стабільність гривні, активний вихід українського виробника на європейські ринки, лібералізація економіки, а також підвищення фрінансової грамотності населення та бізнесу. Ознайомлення 3 особливостями фрінансового лізингу як інструменту фрінансування дає змогу малому та середньому бізнесу скористатися його доступністю та перевагами перед кредитом [7].

Інформація щодо строку дії договорів фінансового лізингу,

Таблиця 4 укладених протягом звітного періоду

\begin{tabular}{|c|c|c|c|c|}
\hline \multirow{3}{*}{ Період } & \multicolumn{4}{|c|}{ Розподіл вартості договорів фінансового лізингу, } \\
& \multicolumn{3}{|c|}{ укладених потягом звітного періоду, за терміном іх дії, млн. грн. } \\
\cline { 2 - 5 } & $\begin{array}{c}\text { Менше або дорівнюе } \\
\mathbf{2} \text { рокам }\end{array}$ & $\begin{array}{c}\text { Більше як 2 або } \\
\text { дорівнюе 5 рокам }\end{array}$ & $\begin{array}{c}\text { Більше як 5 або } \\
\text { дорівнюе 10 рокам }\end{array}$ & Більше як 10 років \\
\hline 2017 рік & 3251,4 & 9546,3 & 170,0 & 0,0 \\
\hline 2018 рік & 5069,4 & 14992,8 & 2130,5 & 0,5 \\
\hline 2019 рік & 6477,4 & 17375,7 & 1277,9 & 1113,7 \\
\hline
\end{tabular}

Джерело: [5, с. 17] 
Використання лізингу для якісного оновлення технічної бази підприємства можливо за умови постійного розвитку внутрішнього лізингового ринку України. Одним з основних недоліків, що перешкоджають його становленню $є$ недосконалість нормативно-правової бази, а саме:

- нестабільність законодавства, що спричиняє ризики для лізингу як довгострокової діяльності;

- складність оформлення лізингової угоди через велику кількість учасників;

- неоднозначність трактування дефрініції dpiнансового лізингу, що ускладнюе встановлення термінів;

- додаткова сплата податку на додану вартість під час набуття лізингоодержувачем права власності на об'єкт лізингу;

- складність процедури повернення прав на володіння майном;

- наявність ризику несплати лізингових платежів або неповернення об'єкта лізингу.

Також варто зазначити, що стрімкому розвитку лізингового ринку можуть перешкоджати такі фрактори як:

- фрінансова криза.

- політична нестабільність.

- недостатня кількість кваліфрікованих кадрів у сорері лізингу.

- недостатне поширення інформації про переваги лізингу для малого та середнього бізнесу.

- низький рівень платоспроможності лізингоодержувачів.
Однак, високий рівень поширення лізингу характерний для усіх розвинених країн, оскільки він має свої переваги в оновленні технічної бази підприємства та надає лізингоодержувачу такі можливості:

- запобігти витратам, що виникають внаслідок морального та фрізичного зносу обладнання;

- випробувати техніку перед купівлею;

- орендувати обладнання, що необхідне лише на сезонний термін;

- уникнути негайного внеску всіх платежів;

- використовувати нові технології без великих капіталовкладень;

- придбати обладнання за залишковою вартістю після завершення лізингової угоди;

- переносити величину лізингових платежів на собівартість товарів та послуг, що виготовляються або надаються.

Висновки i пропозиції. Ринок лізингу в Україні розвивається, проте потребуе уваги з боку уряду та вдосконалення його нормативноправової бази. В умовах нестачі власних коштів підприємства лізинг є вигідним для оновлення його технічної бази і має достатньо вагомих переваг. Досвід зарубіжних держав сприяе виявленню недоліків та вдосконалення можливостей лізингової діяльності в Україні. Доцільно проводити роботу з міжнародними фрінансовими групами щодо популяризації українського лізингового ринку та зацікавлення їх у інвестуванні в лізингову сореру України.

\section{Список літератури:}

1. Про лізинг: Закон України від 16 грудня 1997 року № 723/97-BP. URL: https://zakon.rada.gov.ua/laws/show/ v_104800-98\#Text (дата звернення: 05.04.2021).

2. Про внесення змін до Закону України "Про лізинг" від 11 грудня 2003 року 1381-IV. URL: https://zakon.rada.gov.ua/ laws/show/1381-15\#Text (дата звернення: 12.04.2021).

3. Статистичний щорічник України 2019 рік. Держстат України. 2020. URL: https://ukrstat.org/uk/druk/ publicat/kat_u/2020/zb/11/zb_yearbook_2019.pdf (дата звернення: 07.04.2021).

4. Горідько О.В., Якимова В.І., Дудчик О.Ю. Фінансовий лізинг як інструмент інвестування. Ефективна еконоліка. 2017. № 11.

5. Підсумки діяльності фінансових компаній та юридичних осіб (лізингодавців) за 2019 рік за даними Державного реестру фінансових установ. URL: https://www.nfp.gov.ua/files/OgliadRinkiv/FK/FK_IV_kv_2019.pdf (дата звернення: 09.04.2021).

6. Левченко О. А. Удосконалення інструментарію фінансово-кредитного механізму забезпечення лізингових операцій в Україні. Науковий вісник Херсонського державного університету. 2018. Випуск 30. Частина 4. С. 89.

7. Офіційний сайт Українського об’єднання лізингодавців. URL: http://uul.com.ua/ (дата звернення: 12.04.2021).

\section{References:}

1. Pro lizynh: Zakon Ukrainy vid 16 hrudnia 1997 roku № 723/97-VR [On leasing: Law of Ukraine of December 16 , 1997 № 723/97-VR]. URL: https://zakon.rada.gov.ua/laws/show/v_104800-98\#Text (accessed 05 April 2021).

2. Pro vnesennia zmin do Zakonu Ukrainy "Pro lizynh" vid 11 hrudnia 2003 roku 1381-IV [On Amendments to the Law of Ukraine "On Leasing" of December 11, 2003 1381-IV]. URL: https://zakon.rada.gov.ua/laws/show/138115\#Text (accessed 12 April 2021).

3. Derzhavna sluzhba statystyky Ukrainy (2020) Statystychnyi shchorichnyk Ukrainy 2019 rik [Statistical Yearbook of Ukraine 2019]. Kyiv: State Enterprise "Derzhanalitinform".

4. Horidko O.V., Yakymova V.I., Dudchyk O.Yu. (2017) Finansovyi lizynh yak instrument investuvannia [Financial leasing as an investment tool]. Efficient economy, no. 11.

5. Pidsumky diialnosti finansovykh kompanii ta yurydychnykh osib (lizynhodavtsiv) za 2019 rik za danymy Derzhavnoho reiestru finansovykh ustanov [Results of financial companies and legal entities (lessors) for 2019 according to the State Register of Financial Institutions]. URL: https://www.nfp.gov.ua/files/OgliadRinkiv/ FK/FK_IV_kv_2019.pdf (accessed 09 April 2021).

6. Levchenko O.A. (2018) Udoskonalennia instrumentariiu finansovo-kredytnoho mekhanizmu zabezpechennia lizynhovykh operatsii v Ukraini [Improving the tools of the financial and credit mechanism for leasing operations in Ukraine]. Scientific Bulletin of Kherson State University, vol. 30, no. 4, pp. 89.

7. Ofitsiinyi sait Ukrainskoho obiednannia lizynhodavtsiv [Official site of the Ukrainian Association of Lessors]. URL: http://uul.com.ua/ (accessed 12 April 2021). 